\title{
E-Consumers and Local Food Products: A Perspective for Developing Online Shopping for Local Goods in Poland
}

\author{
Anetta Barska ${ }^{1}\left[\right.$ and Julia Wojciechowska-Solis ${ }^{2, *}$ (1) \\ 1 Faculty of Economics and Management, University of Zielona Góra, 65-246 Zielona Góra, Poland; \\ a.barska@wez.uz.zgora.pl \\ 2 Faculty of Agrobioengineering, University of Life Sciences in Lublin, 20-950 Lublin, Poland \\ * Correspondence: julia.wojciechowska@up.lublin.pl
}

Received: 28 May 2020; Accepted: 15 June 2020; Published: 18 June 2020

\begin{abstract}
The constant development of consumer awareness regarding sustainable development has spread to food markets. Decisions related to food consumption are increasingly becoming, for consumers, an opportunity to demonstrate a specific value system, contesting mass and globally distributed food. Local products began to appreciate local produce, which is the opposite of mass production. Local food is gaining popularity, being perceived as healthier, unprocessed, and containing fewer preservative compounds, while also requiring fewer natural resources, leading to a lower environmental footprint. The phenomenon of shopping virtualization has also been growing in strength lately, especially among food consumers. Although Polish food e-commerce is still relatively undeveloped, online food sales have been the fastest growing category of Internet sales. According to experts, by 2026, nearly $40 \%$ of all products globally will be sold online. The main purpose of this article was to identify the behavior of Polish consumers shopping online for local food products and to identify barriers to purchase. Our findings were then used to determine development opportunities for this form of trade in relation to local food in the light of new legislative solutions currently in force in Poland. As part of the research procedure, an extensive literature review was carried out. In addition, some of the research findings were cited regarding consumer behavior in the local food market, conducted on a population of 1067 respondents. The study showed that Polish e-consumers of local products are usually aged 30-40, well-educated, and are in a good financial situation. Respondents pointed to high prices as the main barrier to buying local products via the Internet, a drawback which may be remedied to some extent by the recently adopted legislative solutions falling under the scope of what is termed in Poland as agricultural retail trade as well as by the promotion of short supply chains such as the Polska Smakuje initiative.
\end{abstract}

Keywords: consumer behavior; support for farmers; sustainable development; well-being of local producers

\section{Introduction}

Food products in Poland are sold mainly through traditional distribution channels, with online sales accounting for approximately $1 \%$ of the total value. It should nevertheless be emphasized that online food sales are the fastest growing category of shopping via the Internet. According to experts, by 2026 , nearly $40 \%$ of all products globally will be sold online. In Poland, this share currently stands at just $7 \%$. The online channel has seen a much more pronounced dynamic in other countries- the latest International Recruiting Center (IRC) Agency report showed that online sales in the fast-moving consumer goods (FMCG) segment in Italy and Spain are even recording a double-digit 
growth by $42 \%$ and $29 \%$, respectively. According to the report, in the next five years, the online sales of FMCG will increase by $54 \%$. Similar conclusions follow from the Nielsen report [1] whose authors indicate that global online sales for FMCG are growing four times faster than offline sales, and a substantial e-commerce growth in the FMCG sector is forecast in European markets for the coming years. This dynamic growth is expected in light of growing professional activity, the increase in the role of leisure, growing congestion, and also the growing popularity of the convenience trend. In Poland, one factor that triggering the development of online food distribution channels on the side of food producers may be the appearance of regulations for managing agricultural retail trade (abbreviated as RHD in Polish). Consumers also turn to the online channel when looking for something specific and that includes local products bearing certificates and labels attesting their high quality. There are also such elements as uniqueness, specific origin, or the use of traditional production methods in their elaboration according to relevant culinary heritage (recipes passed down from generation to generation) $[2,3]$.

The main purpose of this article is to identify the behavior of Polish consumers when shopping online for local food products and to identify purchase barriers. The segment of e-consumers of local products (ELP) is relatively small, but it is promising. Current trends in food markets show that educated consumers have emerged who prefer high-quality, tasty food obtained as per the principles of sustainable development. Legislative solutions implemented in Poland in the field of agricultural retail development have improved consumer access to products in this segment, which can significantly boost sales of local products via the Internet, making the undertaking of this research topic all the more justified from both the cognitive and the applied perspective.

Research questions:

RQ1: Are there similarities between ELP and the total sample in terms of selected criteria such as age, share of local products in total food purchases, and willingness to pay?

$\mathrm{RQ2}$ : What is the importance of selected features of food products to respondents representing consumers using web applications compared to other consumers?

RQ3: What are the criteria for evaluating the authenticity of local food among customers buying food online and offline?

RQ4: What are the reasons for buying local food online?

$\mathrm{RQ5}$ : What are the barriers to buying local products as viewed by e-consumers?

This article explores a segment that can be considered both niche and forward-looking, the latter evidenced by the purchase of local food products on online platforms such as the already mentioned "Polska Smakuje", launched by the Polish National Center for Agricultural Support.

Statistica 13 PL (StatSoft Inc., Tulsa, OK, USA) software was used for statistical analyses. It included: Descriptive Statistics, Discrimination Analysis, Regression Analysis, and T-Test. Prior to the analysis, multivariate normality was tested, checking each variable for distribution normality. It was assumed that the variance matrices of the variables were homogeneous in groups. Statistically significant differences were determined for the mean, whose probability of randomness was lower than $p<0.05$.

\section{Theory and Background}

\subsection{Changes in the Behavior of Polish Consumers in the Food Market}

The economic and social development of economies, and with them constant structural and technological advances in the environment, have a significant impact on the evolution of consumer attitudes and behavior in the food market. The growing diversity of consumers' expectations towards food results is, on the one hand, from consumer contacts with other cultures and, on the other hand, from the pursuit of their own cultural values and national identity [4]. Food consumption is increasingly intertwined with various lifestyles, meaning that different, sometimes strongly diverging, images and expectations are projected onto food products [5]. A study by the consulting company Roland Berger reports that changes in the behavior of Polish consumers are primarily a consequence 
of a fast lifestyle, the creation of a new family model, and increased product awareness. Fast-food, slow-food, conventional, ecological, food additives, and genetic modifications are the terms of a new life philosophy [6]. A fast lifestyle is a response to increasing employment, an increasing amount of time spent at work, and an increasing range of leisure opportunities. This all means that the consumer has less and less time to make purchases. Single-person households have given rise to a new family model, while the ubiquitous availability of the Internet has prompted a growing awareness among consumers about the goods and services they can use. In addition to product awareness, the authors of the report also point to the growing consumer purchasing awareness regarding the very place of purchase. The demand for premium products is on the rise due to people's increased focus on health [7]. When choosing food products, the consumers increasingly take into account the principles of rational nutrition and their expectations towards food growth, with their behavior reflecting their desire to stay healthy or regain health, improve life quality, or maintain/reduce weight [8]. Decisions related to food consumption are increasingly becoming an opportunity for consumers to demonstrate a specific value system, contesting mass and globally distributed food. Consumers are becoming more aware and feel a greater sense of responsibility for the state of the natural environment in relation to daily behavior within the confines of their local community. Products seen as natural or local are perceived as ecological enough to influence the purchasing decision [9]. Sustainable consumption is thus gaining traction in the food market, and it is aimed at finding an optimal level of consumption that allows for meeting basic needs and enjoying a high quality of life while minimizing the exploitation of natural resources and leaving a smaller environmental footprint. Therefore, the present and future generations strive and will continue to strive towards maintaining a balance between economic, human, and natural capital [10-12]. Sustainable consumption is overall determined by three principles: economic, ecological, and social rationality [13]. Aspects such as health, consumer patriotism, and ecology are becoming important, too. Interestingly enough, these developments go hand in hand with a decline in consumer trust in the food market. According to the 2015 Edelman Trust Barometer, trust in the food industry has been systematically on the downfall, dropping to $57.5 \%$ in 2015. The largest decrease in trust was reported in the Netherlands (from $65 \%$ down to $59 \%$ ). This is probably due to food fraud and incidents related to food safety at various stages of the food supply chain. Unlike most European Union (EU) countries, Poland saw the largest increase in trust (by $9 \%$, from $42 \%$ up to 51\%) during the period 2014-2015 [14]. The future growth of food markets depends, to a large extent, on the ability of the food industry to regain consumer trust and establish new institutional solutions that will guarantee food quality in a credible way [5]. This has led many consumers to become interested in traditional and regional food, with these products providing an alternative to industrial food. Consumers from farm households (in which someone was raised on a farm, or had parents who were raised on a farm) had a preference for locally grown food and were willing to pay a price premium for it [15]. Limiting the quantity of consumption in favor of its quality has underpinned the emergence of the slow food movement, promoting peaceful and rush-free food consumption [16]. Advocates of this movement point to the importance of product origin and the possibility of treating cooking as a ritual that strengthens family bonds, preparing meals according to accepted recipes [17]. This is, of course, the opposite of popular fast food. However, not every buyer can afford to live in harmony with slow food, given that these products tend to come with a higher price tag. Another phenomenon that has been on the rise is home-centeredness, understood as the transfer of consumption from external establishments to the home, which is where needs are now met [18]. The combination of this type of behavior with modern technology inevitably leads to online purchases. Virtualization of purchases is gaining more and more recognition among consumers and retailers, which is a consequence of the growing popularity of the Internet, limited time resources, and simply the convenience of this form of shopping. Sellers primarily gain increased market penetration [19]. 


\subsection{The Consumer Towards Local, Regional and Traditional Food Products}

The health attitudes are conducive to the growing interest in local, traditional, and regional food-a category that is difficult to define due to the fact that it tends to be understood broadly and in many different ways. In this article, attention is focused on local food and, hence, further considerations will not go beyond that topic area. Local food comprises products that residents of a region identify with and that remind them of a place that-from their local perspective-is common and ordinary. Such local products are obtained in a non-industrial, non-mass, and environmentally-friendly way. They are produced by local farmers from local raw materials using, to that end, local methods. They are also burdened with smaller transportation costs and have a positive impact on the environment, being at the same time both special and specific to people from outside the region [20]. It is worth emphasizing that, thanks to the development of the local food sector, local economies have sprung up, the carbon footprint of food distribution has been reduced, households' food security has risen, people with low incomes have gained access to good food and a healthy diet, small-sized enterprises have been supported, and small farms have become more profitable [4,21,22]. Consumers most often interpret the term "local food" in the context of a distance traveled by food during transportation from the place of its production to the place of its sale $[23,24]$, or with reference to administrative boundaries such as states, provinces, or voivodships [25]. However, it should be stressed that the terms "local production" and "local food" primarily indicate to consumers a specific combination of attributes related to the product such as "freshness" and the socio-economic environment that benefits from the development of such concepts of food production and distribution [26]. Consumers often associate local products with either selling or sharing food with their neighbors and members of the local community. The term "local food" also brings to consumers' mind a specific emotional context and the idea of building social relations.

From the consumer's perspective, local products stand out because of their unique taste values, which are a combination of specific characteristics of raw materials, processing, and origin that in turn determine the authenticity of this food category [4]. Local food is perceived as healthier, unprocessed, and containing fewer preservatives. At this point, it might be worth drawing attention to the fact that consumers view food produced with a significant interference of processing as carrying a higher level of risk. Similarly, they are skeptical about the packaging of food products involving the use of modern technologies [27]. While new food technologies do indeed enable innovation in the food sector, not all technologies are equally embraced by consumers. Some may be a reason for concern among certain consumer groups who are skeptical about new solutions. Food technologies such as nanotechnology have great potential for generating radically new food products, as does gene technology, but, overall, they are not well received in Europe [28]. Some consumers express their confidence in natural, unprocessed food products [29]. A study by P. Tenbült et al. [30] points out that consumers coming across two products of identical chemical composition-one natural and the other artificial/genetically modified-will choose the natural product. Buyers perceive food additives differently, e.g., acceptance of functional food is to a large extent determined by the type of additional ingredients and their origin, and whether they are natural or artificial [31]. As already highlighted, the attribute of local products is their quality, interpreted as freshness and naturalness. Food-consumption decisions are increasingly becoming an opportunity to demonstrate a specific system of values, or to challenge mass and globally distributed food products. By extension, consumers are becoming more and more aware of-and responsible for-the natural environment, especially concerning everyday behavior related to their functioning in the local community. Furthermore, food origin is becoming the leading purchase criterion [32]. Local origin, or locality, is a complex food attribute, being the sum of sub-attributes such as freshness, seasonality, naturalness, and territoriality. Local food products are opted for because consumers believe they include one or more of these sub-attributes [33].

Local food brings benefits, not only to consumers, but also to producers. First of all, production of this type of food supports the local farming community and small businesses, forging a sense of trust between producers and consumers. It is an expression of striving for fair remuneration arising 
from the effort to preserve a regional landscape and identity. Supporting local economies is one of the reasons why consumers choose local food products. In their view, the production and distribution of food products referred to as "local" contributes to the development of rural areas and responds to their self-imposed need to support the local economy. The development of local food distribution can become an important element of a region's promotion, help create jobs, and therefore, in a tangible way, support the development of local economies [2,34].

Food from local production is part of the concept of sustainable consumption, contributes to the reduction of environmental costs related to food distribution, and paves the way for dialogue between producers and consumers, thereby supporting the development of local communities. This indicates the legitimacy of further development and promotion of such food distribution concepts in Poland, given their potential to support regional development while staying true to the principles of sustainable development in the environmental, social, and economic dimension $[2,34,35]$.

Buyers of local and regional food are guided by the unique taste and aroma as well as by the high quality, which is due to the use of age-old recipes [36]. The local product has a heavy impact on the consumer's mentality, at least as powerful as that of an ecologically certified product [9]. The main reason for shopping for traditional and regional foods with Protected Geographical Indication (PGI), Protected Designation of Origin (PDO), and Traditional Specialty Guaranteed (TSG) labels is the guarantee of the product origin [37]. Products perceived as natural, local, or traditional are perceived as ecological enough to influence the purchasing decision. Perceived benefits of local foods are rather similar to those of organic products, including aspects of taste, food safety, animal welfare, and reduced environmental impacts [38]. The consumers in Poland obtained information on regional food products from their friends or family and from television, the Internet, and regional fairs. The problem is the low number of possibilities for buying regional products. Television and the Internet have great potential to educate consumers [21]. Zakowska-Biemans, together with their team, proved that $78 \%$ of respondents admitted they bought this food. The unquestionable majority of respondents perceive it in a positive way and its taste qualities are of special significance. The respondents declared that they liked trying products characteristic of a given region, because their taste and smell suited them. They are certain of nutritional values of local food and its positive impact on their health [27]. Researcher P. Bryła has identified the variable of impact on consumer behavior on the regional food market, covered by the importance of brand and retailer trust on the food market and the role of quality signs in regional food purchases. The regional product provides a relative assurance of authenticity guaranteed by an independent authority. Polish consumers prefer buying regional products in shops owned by producers, rather than large distribution networks, and have attitudes of national ethnocentrism regarding the regional food market [39]. Among factors restricting the purchase decision, the following were named: lack of knowledge of such products, lack of information on place of distribution, and insufficient knowledge of the markings of this products [27]. Research on Romanian consumers suggests that the idea of organic products is the subject of a mental projection that regulates itself, especially in the symbolic system of healthy living [9]. Research of Czech scientists shows that the origin of food plays an important role in consumer purchase decision-making [40]. At the level of purchase decision, this product is a projection determined by the knowledge level, culture, tradition, and emotional landscape of the consumer [6]. Kalabova, together with their team, proved that there was no association between the following variables-levels of preferences and gender or the size of the town of residence of the respondents. He identified a moderately strong degree of association between the selected values of the traditional and regional foods and respondents' occupation, age, and education [40]. Brown proved that the attitude towards local food is dependent on the place of origin of the respondents.

\subsection{Food E-Commerce in Poland}

The e-commerce market in Poland is growing at an annual rate of $18 \%$ and is expected to break the PLN (polish national currency) 47 billion mark by the end of this year. Equally dynamic is the 
growth in the percentage of online consumers in Poland. In 2019, as many as 62\% of Internet users purchased things online-compared to $56 \%$ in 2018 and 54\% in 2017. A slightly slower increase in Internet users-currently at 26\%-was recorded for shopping in foreign stores (against $23 \%$ in 2018 and $16 \%$ in 2017). One in five Polish consumers (22\%) has at some point bought food products online, while another $27 \%$ are planning such a purchase in the future. In the last quarter of $2018,37 \%$ of Poles made a purchase online [41]. Items most often purchased online include: clothing, electronic equipment, footwear, toys, children's accessories, and automotive products [42,43]. However, with regard to food, Polish e-commerce still has a long way to go, meaning there is a slow but consistent increase in the number of customers buying food online. Moreover, consumers who have been satisfied with an earlier purchase are willing to shop for food online again [44,45]. Online shopping is more often declared by women ( $27 \%$ compared to $16 \%$ among men) and by people with higher education (31\%) [46]. Both demand and supply stand behind the development of e-commerce. An important determinant here is progress in the area of information and telecommunication technologies. In 2018, 84.2\% of Polish households had access to the Internet-up 2.3 percentage points from 2018 and 8.4 percentage points from 2015. In annual terms, the share of households using the Internet via broadband connection increased by 1.7 percentage points. In 2018, the share of Internet users was $77.5 \%$; i.e., 1.6 percentage points more than in the previous year of which regular users (accessing the worldwide web at least once a week) was $74.8 \%$; i.e., 2.1 percentage points more than in 2017 [47]. Other elements that are barriers to e-commerce development are additional shipping charges, lack of physical interaction with the product, and the time of order fulfillment. The most important advantages of online shopping are convenience and saving time, while the most significant disadvantages for consumers involve the risk of incorrectly valuating some products and apprehension about the selection and handling of perishables such as vegetables, eggs, and meat products [48]. Customers express concerns about the quality of such products and their price. Reluctance to buy food online is not necessarily due to the specificity of the food product itself. One can still occasionally come across stores offering fresh products, which are usually heavily processed. Barriers to food e-commerce are in fact similar to those found in other areas. That is to say, e-consumers are mainly concerned about the timeliness of deliveries, the security of transactions, and whether or not the ordered goods will meet their expectations [49].

However, with regard to food, Polish e-commerce is still in diapers, despite the slow yet systematic increase in the number of customers buying food online. According to PizzaPortal's 2018 report, Click and Eat on the food supply market in Poland [50], the food orders market in 2018 was approximately PLN 6 billion and accounted for 25\% of the total restaurant market turnover. Consumers satisfied with an earlier purchase are increasingly more willing to return to this form of shopping for food [45]. On the downside, they are discouraged by additional delivery fees, lack of physical contact with the product, and delivery time. They have concerns regarding product quality and price. Having said that, reluctance to buy food via the Internet does not need to be due only to food specificity. One can still occasionally come across stores offering fresh products, although these are usually highly processed.

Let us note that research into e-consumer behavior in relation to food products is also becoming increasingly abundant in the world literature, and this subject is bound to gain even more significance over time due to increased isolation and a sense of threat as to the safety of consumed food in reaction to the SARS-CoV-2 coronavirus pandemic. An attempt to characterize the e-consumer of food products was undertaken by Wang et al. [51], Kaur et al. [52], and Kooti et al. [53]. The cited studies concern different geographical areas and different groups of food products. An analysis of the research results to date indicates that age and gender are strongly correlated with the tendency to shop online, whereas the available income, measured by the place of residence of individuals (i.e., in either more or less affluent areas) is strongly linked with both the frequency of online purchases and the amount of money spent there [54].

P. Bryły [43] made an attempt to characterize the Polish e-consumer in the organic market. The author analyzed selected features, attitudes, and opinions of e-consumers buying organic food online in Poland. The study showed that age, income, price factor, product appearance, and quality 
labels turned out to be statistically significant determinants of shopping behavior on the Internet in terms of buying organic food. Higher income and quality-label drive increase the likelihood of being an ecological e-consumer, while older age and greater importance being attached to product appearance decrees its likelihood. Barriers to food e-commerce are similar to those found throughout e-commerce as a whole. E-consumers have concerns about the timeliness of deliveries, the security of transactions, and whether the goods they order will correspond to their expectations [55].

However, the frequency analysis performed in this article showed that research into Polish people's attitude towards local and regional products purchased online is rare. The available knowledge therefore needs to be supplemented, especially in the face of the permanent evolution of consumer behavior stemming from so-called civilization changes. Undertaking this research topic has not only a cognitive but also an applied justification. Knowledge acquired in the process can prove practically useful, with entrepreneurs being able to refer to it when developing effective marketing strategies in target markets and growing their business overall. This knowledge will also come in handy in adapting the existing strategies and strengthening market position to curb global competitors.

\subsection{The Concept of Short Food Supply Chains}

The increasing demand for local and regional products, along with changes in consumer awareness and their desire to learn about the origin of products, are providing an impulse to create short supply chains [56]. Short supply chains bring consumers closer to food sources and improve communication systems between the producer and the consumer regarding the signals of product origin and quality, potentially increasing the reintegration of agriculture towards more environmentally sustainable types of production [5]. A short supply chain offers many alternatives for supplying local food, with the most popular such sources being: agricultural markets, direct sales from the farm, and consumer cooperatives, also known as food cooperatives [57]. In addition to the limited number of intermediaries, the basic criteria for defining short supply chains are the shorter distances between producers and consumers, as well as mutual understanding and communication between the two [58]. The development of local food production and distribution systems is also reflected in the dissemination of the concept of Community Supported Agriculture, in which consumers become co-responsible in financial and organizational terms for food production on a farm [59]. Also conducive to building short supply chains is the growing importance of e-commerce in the food products segment.

Although Polish consumers still prefer traditional shopping, the e-shopping market for food in Poland is on the rise. Mail-order sales are convenient, and it seems that, similarly to many other EU countries, they have a good forecast for growth. Introduced legislative solutions related to Agricultural Retail Trade facilitate consumers' access to good and healthy food. Agricultural retail trade is a form of retail trade for which separate regulations in the field of supervision of official food control bodies have been adopted in Polish law and for which certain tax preferences have been introduced. As part of such trade, it is possible, among other things, to process and sell manufactured food products to end consumers and, as of 1 January 2019, also to establishments conducting retail trade oriented towards the end consumer within a limited area (direct sale to catering establishments).

The Polish National Agricultural Support Center-as part of the campaign "Polska smakuje" (lit. "Poland tastes")-launched the website www.polskasmakuje.pl and the mobile application of the same name, thus creating a communication platform between food producers and consumers. Every farmer or local food producer who is looking for potential buyers of their products can now use the free application to that end, which allows consumers to obtain information about farms involved in agricultural retail trade and to purchase local products according to their needs [60].

\section{Materials and Methods}

The study used the diagnostic survey method with an independently developed questionnaire. The questionnaire contained three sections touching on topics such as: knowledge about local food products, reasons (motives) for their purchase and consumption, and sociodemographic characteristics 
of respondents. Concerning the purpose of this article, which focusses on the behavior of Polish consumers when shopping online for local food products, only some questions from the survey questionnaire made the cut. The questionnaire contained 20 questions regarding the subject of local and regional products, as well as questions about the characteristics of respondents, such as: age, gender, place of residence, and social/professional status. Only research questions about local products are presented in this article. The questionnaire was prepared in Polish due to the research environment. The proprietary questionnaire primarily employed five-point Likert scales containing the following response categories: "I strongly disagree", "I disagree", "Neither agree nor disagree", "I agree", and "I strongly agree". In addition, the five-point rank scale with the following categories were also used: "very important", "important", "slightly important", "not very important", "not important at all". We used descriptive statistics for the characteristics of our sample to describe the studied groups. Discrimination analysis are decisions that variables distinguish (discriminate) naturally emerging groups. Regression analysis was implemented to assess the relationships between the processes examined. We used $t$-test analysis to compare the means of the two E-consumers of Local Products (ELP) and Total Sample (TS) groups. The author's original questionnaire was prepared on the basis of a focus interview, and it was structured during pilot studies. Cronbach's $\alpha$-test was used for the evaluation, with its values contained within the range (0.70-0.90), which allowed us to positively evaluate the measurement scales in terms of internal consistency and reliability [61,62]. When determining the size of the sample, the confidence level was adopted at 0.95 and the estimated fraction size at 0.50 , while the maximum error was gauged at 0.03 . The sample was representative of Poland's entire adult population, or approximately 31,532,048 people [63]. The size of the research sample was set at 1067 respondents, taking into account: place of residence (village, towns up to 30,000 residents, and cities above 30,000 residents), age (from 15 to 65 years of age, with an average of 40 so that the sample structure corresponds to Poland's general population for this range), and gender from six different Polish regions. All six regions are represented in the research sample: central, 220; southern, 222; eastern, 188; southwestern, 109; northwestern, 164; and northern, 164 respondents. When designing the sample with reference to gender and place of residence, a quota sample was proposed in which respondents were selected based on their availability until the end of the research proceedings. In the sample, women constituted $52.3 \%$ and men $47.7 \%$ of respondents. According to Eurostat data, $7 \%$ of Polish citizens say they shop online for local food products, a piece of data that was also worked into the research sample. In the total sample examined, the population representing people shopping for local products online is not very numerous, therefore caution should be exercised when it comes to the generalization of these findings regarding the entire population. Instead, our results should be seen as an interesting point of departure for future research. The study was conducted by telephone (more specifically, using the computer-assisted telephone interviewing-CATI) method, applying all the criteria outlined. The research was carried out from January to June 2019.

\section{Results}

According to the data obtained in this study for Poland, it was women who were more likely to shop for local products online (in the e-consumer group, women accounted for $60 \%$ of the population, while there were $52.3 \%$ in the entire surveyed population containing people preferring both online local food distribution channels and traditional ones).

Significant differences were observed between buyers in stationary local food stores (market stalls, fairs, and shops at farms selling their own produce) and the total sample due to certain socio-demographic variables describing them. E-consumers of local products are usually younger and more well-off, and they tend to be dwellers of large cities ( $84 \%$ of the sample). Not surprisingly, e-consumers have a greater share of local products in total food consumption (understood as high-quality products obtained in line with the principles of sustainable development expressed as caring for the natural environment and improving the well-being of the local community and the region where they 
are produced). They are also marked by a greater willingness to pay more for local food compared to conventional products (Table 1).

Table 1. Comparison of e-consumers of local products with the total sample by: age, share of local products in total food purchases, and willingness to pay.

\begin{tabular}{ccccccc}
\hline \multirow{2}{*}{ Measure } & \multicolumn{2}{c}{ Respondents' Age } & \multicolumn{2}{c}{$\begin{array}{c}\text { Share of Local Products in } \\
\text { Total Food Purchases (\%) }\end{array}$} & \multicolumn{2}{c}{ Willingness to Pay More (\%) } \\
\cline { 2 - 7 } & ELP & TS & ELP & TS & ELP & TS \\
\hline Mean & 34.89 & 39.78 & 35.98 & 29.16 & 24.57 & 18.59 \\
\hline $\begin{array}{c}\text { Standard } \\
\text { deviation }\end{array}$ & 14.75 & 14.77 & 26.85 & 22.16 & 20.46 & 15.20 \\
\hline Min. & 22.00 & 16.00 & 1.00 & 1.00 & 0.00 & 0.00 \\
\hline 1st quartile & 29.00 & 28.00 & 10.00 & 10.00 & 7.00 & 5.00 \\
\hline Median & 31.00 & 39.00 & 25.00 & 20.00 & 15.00 & 10.00 \\
\hline 3rd quartile & 45.50 & 49.00 & 60.00 & 40.00 & 25.00 & 20.00 \\
\hline Max. & 60.00 & 65.00 & 92.00 & 100.00 & 100.00 & 100.00 \\
\hline
\end{tabular}

Note: ELP—e-consumers of local products (75 respondents); TS—Total sample (1067 respondents). ELP—a group of people who declares the purchase of local products also via the Internet. The "Polska Smakuje" application is a platform where local products can be purchased. TS - is a total sample of people purchasing local products that has been adapted to the socio-demographic distribution of the country.

As part of the study, respondents were asked to provide feedback on selected features of local products available on the market through the web application and offered in traditional sales (Table 2). Although factors such as product designation, price, or place of production ranked high in both groups and their impact on purchasing decisions for the group preferring the traditional way of shopping was greater, the reported differences were not statistically significant at the level of $p<0.05$. Significant differences can be observed for features such as appearance/taste, smell, and trust in the seller, while for online shoppers, these features were less important. (Table 2).

Table 2. Comparison of e-consumers (ELP) with the rest of the sample (OR) in terms of the importance of selected features of local products.

\begin{tabular}{ccccc}
\hline \multirow{2}{*}{$\begin{array}{l}\text { Selected Features } \\
\text { of Local Products }\end{array}$} & \multicolumn{2}{c}{ Mean } & \multirow{2}{*}{ t-Test } & \multirow{2}{*}{$\boldsymbol{p}$-Value } \\
\cline { 2 - 3 } & ELP & OR & & \\
\hline Appearance/taste, smell & 3.718 & 4.089 & -3.437 & 0.001 \\
\hline Designation & 3.728 & 3.770 & -0.383 & 0.702 \\
\hline Price & 3.574 & 3.766 & -1.774 & 0.076 \\
\hline Place of production & 3.631 & 3.702 & -0.665 & 0.506 \\
\hline Trust in the seller & 3.877 & 4.051 & -1.822 & 0.000 \\
\hline Advertised nutritional values & 3.615 & 3.613 & 0.024 & 0.001 \\
\hline
\end{tabular}

Note: ELP—e-consumers of local products (75 respondents); OR—other respondents (922 respondents).

The criterion "High quality of products" as a factor in evaluating the authenticity of local products was much more often of importance to consumers preferring the traditional way of shopping $(2.799, p<0.001)$ than those who make purchases online $(485, p<0.001)$ (Table 3$)$. In addition, consumers buying products at traditional market stands and stalls identified the "Traditional and natural way of production" as an important criterion in identifying local products. They also more often pointed to their "Health benefits" (1.920). As far as e-consumers are concerned, the values of the classification function reached the levels of 1.120 and 1.729, respectively. Having said that, e-consumers 
pay at the moment of purchase much more attention to the labeling of local products $(0.689, p<0.001)$ than traditional consumers $(0.398, p<0.001)$. Both groups evaluated equally the importance of the looks of a stand or a website where they are shopping for products. The value of the classification function was 1.811 and 1.766 for e-consumers and traditional consumers, respectively.

Table 3. Criteria for evaluating the authenticity of local food among online shoppers compared to consumers who prefer traditional shopping.

\begin{tabular}{cccccc}
\hline \multirow{2}{*}{ Evaluation Criterion } & \multicolumn{2}{c}{$\begin{array}{c}\text { Wilks' Lambda: } \mathbf{0 . 6 2 1} \\
\text { F }=\mathbf{3 5 . 7 5 3} \boldsymbol{p}<\mathbf{0 . 0 0 1}{ }^{*}\end{array}$} & \multicolumn{2}{c}{ Type of Consumer } \\
\cline { 2 - 6 } & $\begin{array}{c}\text { Wilks' } \\
\text { Lambda }\end{array}$ & F Value & $\boldsymbol{p}$ Value & ELP $\boldsymbol{p}=\mathbf{0 . 5 1 7}$ & $\begin{array}{c}\text { Traditional } \\
\text { Consumers/OR } \\
\boldsymbol{p}=\mathbf{0 . 4 8 3}\end{array}$ \\
\hline Natural method of production & 0.621 & 60.281 & $0.001^{*}$ & 1.120 & 1.371 \\
\hline High product quality & 0.619 & 35.687 & $0.001^{*}$ & 2.485 & 2.799 \\
\hline Data included on the label & 0.589 & 47.182 & $0.001^{*}$ & 0.689 & 0.398 \\
\hline High health benefits of the product & 0.581 & 17.252 & $0.001^{*}$ & 1.729 & 1.920 \\
\hline Retailer (website/stand) & 0.586 & 1.606 & 0.206 & 1.818 & 1.766 \\
\hline Constants & & & 15.179 & 17.270
\end{tabular}

Note: Wilks' lambda is a measure used to assess the discriminant score of the entire model, i.e., all variables present in the model taken together, which the model will have after introducing to it a given variable. It assumes values from 0 to 1; values close to zero point to the high discriminant score of the model. The value of the F statistic reflects the discriminant score of a given variable. Variables are added to the model according to the $\mathrm{F}$ values starting from the variable whose discriminant score is the highest. The tested hypothesis in the model of the authenticity of local food for consumers buying online is whether a variable makes a significant contribution to the model. ELP—e-consumers of local products (75 respondents); OR—other respondents (992 respondents). * Level of significant difference at $p<0.05$.

Table 4 contains a comparison of the importance of the selected elements of shopping online. Respondents were asked to choose at least three elements that would make them use this shopping channel. Analyzing the results obtained, there are differences in the importance of selected elements for ELP and other respondents (OR).

For ELP, convenience was found to be the most important reason for buying local products over the Internet. The ability to save time and the wide assortment offered on websites and in mobile applications came in second and third, followed by the factors of price and flavors evoking childhood nostalgia, which also occupy an important place in the hierarchy of reasons for buying local products online.

For people who usually buy local products at stationary stands, convenience would also be of great importance. In turn, "Access to unique products rarely available in traditional sales" was in second place and "Wider range" came next. For other consumers, the least important factors in favor of online shopping were "Managing orders on an ongoing basis", "Affiliate program in the app", "Being able to correct data", and "Home delivery" (Table 4).

The tests were statistically significant for each motive chosen by the respondent in both groups of respondents for $p<0.05$.

Attention should be drawn to the fact that selling food products online is difficult due to the physical characteristics of a product that is easily spoiled. This requires a highly efficient and organized mediation in physical delivery. Consumers of local products online believe that the biggest barriers to the development of this market are (Table 5): the price one pays for the uniqueness and rarity of the product; expiry date (which is usually shorter due to the lack of preservatives); fear of receiving stale food, fraud on the part of sellers (inauthenticity of the product); and not being able to return the product. 
Table 4. Ranking of validity of motives for buying local products online for ELP and OR.

\begin{tabular}{|c|c|c|c|c|c|c|c|c|}
\hline \multirow[t]{2}{*}{ Variable } & \multicolumn{2}{|c|}{ Rank } & \multicolumn{2}{|c|}{ Mean } & \multicolumn{2}{|c|}{$\begin{array}{l}\% \text { Share of Variable } \\
\text { Significance }\end{array}$} & \multirow[t]{2}{*}{$t$-Test } & \multirow[t]{2}{*}{$p$-Value } \\
\hline & ELP & OR & ELP & OR & ELP & OR & & \\
\hline Convenience & 1 & 1 & 4.282 & 4.153 & 62.4 & 34.6 & 2.257 & $0.023 *$ \\
\hline Saving time & $2-3$ & 7 & 4.014 & 3.924 & 35.3 & 20.8 & 2.303 & $<0.000$ * \\
\hline Wide assortment & $2-3$ & 3 & 4.014 & 4.081 & 35.3 & 29.2 & 1.854 & $0.001 *$ \\
\hline $\begin{array}{l}\text { Access to unique products rarely } \\
\text { available in traditional sales }\end{array}$ & 4 & 2 & 3.991 & 4.113 & 34.9 & 30.2 & 2.851 & $<0.000$ * \\
\hline Sentiment-childhood nostalgia & 5 & 4 & 3.983 & 4.056 & 23.8 & 28.2 & 1.034 & $<0.000 *$ \\
\hline Choosing delivery date & $6-8$ & 8 & 3.444 & 3.816 & 20.6 & 19.8 & 1.136 & $0.012 *$ \\
\hline Making purchases $24 / 7$ & $6-8$ & 9 & 3.444 & 3.755 & 20.6 & 9.8 & 1.082 & $<0.000^{*}$ \\
\hline Supporting local producers & $6-8$ & 6 & 3.444 & 4.000 & 20.6 & 21.2 & 1.335 & $<0.000 *$ \\
\hline $\begin{array}{l}\text { Managing orders on an } \\
\text { ongoing basis }\end{array}$ & 19 & 13 & 3.356 & 3.424 & 16.2 & 0.6 & 1.391 & $<0.000$ * \\
\hline Affiliate program in the app & $10-12$ & 12 & 3.142 & 3.591 & 14.3 & 0.7 & 1.432 & $<0.000$ * \\
\hline Being able to correct data & $10-12$ & 11 & 3.142 & 3.623 & 14.3 & 1.4 & 0.788 & $<0.000$ * \\
\hline Home delivery & $10-12$ & 10 & 3.142 & 3.702 & 14.3 & 2.8 & 1.015 & $<0.000$ * \\
\hline
\end{tabular}

Note: The sum in the column regarding the percentage share exceeds 100 because consumers were asked to indicate at least three criteria. ELP-e-consumers of local products (75 respondents); OR-other respondents (992 respondents). ${ }^{*}$ Level of significant difference at $p<0.05$.

Table 5. Comparison of ELP and OR regarding the importance of selected barriers in buying local products.

\begin{tabular}{|c|c|c|c|c|c|c|c|c|}
\hline \multirow{2}{*}{ Variable } & \multicolumn{2}{|c|}{ Rank } & \multicolumn{2}{|c|}{ Mean } & \multicolumn{2}{|c|}{$\%$ Share of Variable Significance } & \multirow{2}{*}{$t$-Test } & \multirow{2}{*}{$p$-Value } \\
\hline & ELP & OR & ELP & OR & ELP & OR & & \\
\hline Price & 1 & 1 & 3.574 & 3.766 & 45.6 & 62.9 & -1.772 & 0.072 \\
\hline Availability & 2 & 3 & 3.551 & 3.482 & 44.2 & 31.2 & -0.701 & 0.443 \\
\hline Short expiry date & 3 & 2 & 3.484 & 3.521 & 25.4 & 37.1 & -0.774 & 0.457 \\
\hline $\begin{array}{l}\text { Fear of receiving } \\
\text { stale food }\end{array}$ & 4 & 4 & 3.546 & 3.502 & 20.6 & 20.0 & 1.983 & $0.031 *$ \\
\hline Food-related fraud & 5 & 6 & 3.254 & 3.023 & 19.0 & 12.3 & -0.721 & 0.472 \\
\hline No returns accepted & 6 & 5 & 3.144 & 3.101 & 17.4 & 15.8 & 1.024 & 0.282 \\
\hline
\end{tabular}

If we look at the results of barriers in the OR, then consumers also paid the most attention to the price, short expiry date, and availability of local products.

The indicated barriers were more important for ELP than for OR (obtained means were higher); however, these differences were not statistically significant at the level of $p<0.05$. The exception was in "Fear of receiving stale food", which was statistically significant $(p=0.03)$, although in the ranking of both groups it occupies the same position.

Trade of food products in virtual space is difficult to implement in practice. Concerning the trade of local products with unique features (which, in most cases, is also the reason why consumers decide to buy them online in the first place), the consumer is willing to take risks deriving from egocentric and altruistic motives. There is also a statistically significant correlation (Table 6) between the uniqueness of local products and the propensity of consumers to shop for them online ( $\beta=0.111$; $p=<0.001$ ). The variable determining the rarity of local products on the market was rather highly rated 
by consumers, meaning it was of great importance when making shopping decisions online. This can be expressed mathematically as: $y=2.919+0.111 x$ (where $x$ denotes the uniqueness of local products). Lack of a large number of intermediaries, i.e., the possibility to buy directly from the source, also has an important role in the decision-making process of those buying local products $(\beta=0.181 ; p<0.001)$. The mathematical equation for this can be expressed as: $y=4.225+0.181 \mathrm{x}$ (where $\mathrm{x}$ denotes the significance of the supply chain in the producer-consumer relationship). A strong relationship was also observed between consumers' knowledge of local products and the use of websites for buying purposes ( $\beta=0.249 ; p<0.001)$. Overall, the higher the knowledge about the composition of raw materials, nutritional, or health values, the higher the frequency of purchasing and thus also consumption of local products. This can be expressed mathematically as: $y=3.863+0.249 x$ (where $x$ denotes the level of consumer knowledge). The analysis also found no significant correlation between the willingness to pay more for local products purchased online and signaled a weak relationship between the variables importance to local development and purchase decision $(\beta=0.062 ; p=0.014)$. The coefficient showed a positive correlation between the variables, but it was not statistically significant. This can be represented mathematically as: $y=2.738+0.062 x$ (where $x$ denotes the impact of awareness of supporting the locality that the purchased product comes from when making a purchase).

Applications for purchasing food through online channels are popular and widespread among customers who have already used this option and were satisfied with the products they received. All participants in the study representing the sample of e-consumers recommended that other consumers shop online and were able to list websites where it is possible to shop for local products. Not surprisingly, respondents who are willing to pay more for local food value the ability to save time by indicating this variable as one of the main reasons for using the Internet for shopping purposes. In addition, the same respondents value the uniqueness of local products, which are more available on websites than in traditional circulation.

Table 6. Linear regression analysis predicting the attitude of e-consumers of local products.

\begin{tabular}{ccccccc}
\hline Variable & Mean & $\boldsymbol{\beta}$ & Y-Intercept & \multicolumn{3}{c}{ Regression Analysis } \\
\cline { 5 - 7 } & & & & $\mathbf{S E}$ & $\mathbf{t}$ & Level of Significance \\
\hline Product uniqueness/rarity & 3.92 & 0.111 & 2.919 & 1.124 & 1.017 & $<0.001$ \\
\hline $\begin{array}{c}\text { Buying directly from the } \\
\text { manufacturer }\end{array}$ & 3.57 & 0.181 & 4.225 & 0.061 & 3.415 & $<0.001$ \\
\hline $\begin{array}{c}\text { Knowledge about } \\
\text { product/composition/health values }\end{array}$ & 3.62 & 0.249 & 3.863 & 0.865 & 5.115 & $<0.001$ \\
\hline Willingness to pay more & 3.57 & -0.148 & 3.327 & 1.070 & -1.427 & 0.154 \\
\hline Importance to local development & 3.44 & 0.062 & 2.738 & 1.118 & 0.568 & 0.014 \\
\hline
\end{tabular}

\section{Discussion}

The Nielsen report [1] shows that recent economic growth, improved employment prospects, and higher incomes are the propellers of sustainable consumption growth in Poland. Nielsen estimates that Poland's share in total FMCG sales (below 1\% in 2017) will increase to 1.9\% (USD 637 million) in 2022. Thanks to the legislative facilitation of direct sales of (local) food from farmers through the "Polska smakuje" application, the following findings confirm that Poland is a country where online trade of local products can potentially experience dynamic development. This bodes very well for the development of this distribution channel. In the study discussed in this paper, it was found that e-consumers of local products usually fall within the age range of 30-40; i.e., they are at the stage of life when they have a stable financial situation and can afford to spend more on food products, paying attention not only to the price factor, but also to the social, ecological, and health aspect. These consumers are often young parents, and their interest in local products is an expression of their concern for their children. Similar conclusions were presented in a study by Grzybowska-Brzezińska and Rudzewicz [64], who argue that "online food buyers are usually young, well-educated, and in good financial condition". 
South American researchers Hidalgo-Milpa et al. [65] and Espejel-Blanco et al. [66] found that it is women who most often buy local products in an attempt to care for the wellbeing of their immediate family. One of the factors that makes them choose the online channel is the ability to save time. In another study, Götze et al. [67] found that Swiss consumers also expressed their preference for local products that are more expensive (in relation to the aspect of supporting local producers). The ability to save time when making purchases online is appreciated by all participants who engage in such transactions. The development of online food commerce is of great importance, especially in remote areas that consumers cannot physically reach-the solution, then, is to buy online. It should be emphasized that the promotion of short supply chains for local products, an example of which is agricultural trade via the Internet (and the platform "Polska smakuje" in Poland) contributes to the diversification of employment in rural areas by creating non-agricultural sources of subsistence in the countryside and increases the income of agricultural producers. According to Bodini and Zanoli [68], the success factors of food e-commerce should include navigation efficiency and the accuracy of content and information included on an online platform.

In a study conducted in Spain by Fernández-Ferrína et al., [69], research questions were confirmed that there is a correlation between motives that the Spanish researchers termed as ethnocentric in consumers and a tendency to buy local products. Tradition combined with the geographical origin of a product is a strong element of local identity [70], which may lead consumers to at least try and then continue to buy local products, thus supporting local development and improving the financial situation of the local population. In this study, the hypothesis proposed by the Spanish researchers about the existence of a relationship between these variables was confirmed. However, if a purchase is made online and not on a traditional market (physical stands, stalls, fairs, etc.), then the factor of importance to local development does not reveal a strong relationship between these variables.

In the opinion of consumers, the advantages of online shopping for groceries include convenience, better assortment, and price, while the disadvantages relate to the risk of receiving inferior food products and losing the recreational aspect of grocery shopping [71,72].

Packaging could be considered as a barrier to purchasing [73]. The packaging contains all information related to "security", "traceability", and "brand". Properly selected packaging should positively influence consumer purchasing decisions [74].

The quality policy implemented in the EU also gives consumers confidence that they are buying food of very high quality, obtained through unique and traditional methods of production. Due to the large variety of products available on the market, consumers also expect clear and comprehensive information regarding the quality and origin of an agricultural product or foodstuff. Buying directly from the producer, they are sure to receive a high-quality product obtained in accordance with EU standards. Identification and selection of individual products is further facilitated by geographical indications, designations of origin, and guaranteed traditional specialties [52].

According to Markuszewska et al. [58], authors of a report commissioned by the European Commission, the shorter the supply chain, the easier it is to retain and communicate the authenticity and originality of a food product. The European Committee of the Regions [75] called on Member States to outline local food development goals in their own rural development strategies and on the European Commission to accept the definition of local food systems and local food products as well as to introduce new labels and develop common symbols and identification systems for local products. One of the recommendations is that definitions are clear and simple, so as to avoid complicated registration and control procedures. A report from the European Commission [76] indicates that the concept of local food systems suggests that food production, trade, and consumption take place within a relatively small geographical area.

\section{Conclusions}

The completed research and literature analysis make it possible to separate the following conclusions and practical implications: 
The consumer is aware of the fact that local products that are not mass products are, by default, more expensive and that buying at the source, bypassing intermediaries through a short supply chain (Internet), directly supports regional development. From the regional economy's point of view, the development of local food systems and short supply chains are essential due to the economic, environmental, and social benefits that they come with. Further expansion of local food systems requires commitment and partnership between public and private sector entities.

E-consumers consider the higher price, lower availability, and short shelf time as the biggest barriers to the development of local online trade. There is also fear that products delivered will not be fresh, and there is also a fear of unreliable sellers. Partial elimination of these barriers can occur through the implementation of appropriate legislative solutions. From a practical point of view, it is important to support small food producers, as reflected in the adoption on 1 January 2019 of legislative solutions enabling the construction of short supply chains as part of agricultural retail trade, enabling them to benefit from the support offered under financial instruments, which may help reduce their prices and contribute to their greater availability.

Awareness arising from the supporting of local producers was among the ten motives for choosing local products. The possibility of buying local products through online platforms supported by the Polish Ministry of Agriculture and Rural Development should be promoted in the media, given that nearly $85 \%$ of households in Poland currently have access to the Internet.

A well-designed website in the food trade builds trust in the online distribution channel of food products, which can contribute to an increase in the consumption of products purchased this way. A technical support team should be established to support this sales channel.

Author Contributions: Conceptualization, J.W.-S.; methodology, J.W.-S. and A.B.; software, J.W.-S.; validation, J.W.-S.; formal analysis, J.W.-S.; investigation, J.W.-S.; resources, A.B.; data curation, J.W.-S. and A.B.; writing - original draft preparation, J.W.-S. and A.B; writing—review and editing, J.W.-S. and A.B.; visualization, J.W.-S. and A.B.; supervision, J.W.-S.; project administration, J.W.-S.; funding acquisition, A.B. and J.W.-S. All authors have read and agreed to the published version of the manuscript.

Funding: This research received no external funding.

Acknowledgments: This study was funded by the projects: Consumer behavior relevant to the quality of life of the rural population (project supported by the Ministry of Science and Higher Education in Poland-research tasks).

Conflicts of Interest: The authors declare no conflict of interest.

\section{References}

1. Nielsen Report. Future Opportunities in FMCG E-Commerce. Available online: https://www.nielsen.com/ ssa/en/insights/report/2018/future-opportunities-in-fmcg-ecommerce/ (accessed on 31 July 2019).

2. Barska, A.; Wojciechowska-Solis, J. Traditional and regional food as seen by consumers-Research results: The case of Poland. Br. Food J. 2018, 120, 1994-2004. [CrossRef]

3. Jerzak, M.A.; Śmiglak-Krajewska, M. Globalization of the market for vegetable protein feed and its impact on sustainable agricultural development and food security in EU countries illustrated by the example of Poland. Sustainability 2020, 12, 888. [CrossRef]

4. Gutkowska, K.; Zakowska-Biemans, S.; Sajdakowska, M. Preferencje konsumentów w zakresie możliwych do zastosowania innowacji w produktach tradycyjnych. Żywność Nauka Technol. Jakość 2009, 16, 115-125.

5. Renting, H.; Marsden, T.K.; Banks, J. Understanding alternative food networks: Exploring the role of short food supply chains in rural development. Environ. Plan. A 2003, 35, 393-411. [CrossRef]

6. Butu, A.; Vasiliu, C.D.; Rodino, S.; Brumă, I.S.; Tanasă, L.; Butu, M. The anthropological analysis of the key determinants on the purchase decision taken by the Romanian consumers regarding the ecological agroalimentary products. Sustainability 2019, 11, 4897. [CrossRef]

7. Global Automotive Supplier Study 2016-Roland Berger. Available online: www.rolandberger.com (accessed on 2 May 2020).

8. Gracia, A. Consumers' preferences for a local food product: A real choice experiment. Empir. Econ. 2013, 47, 111-128. Available online: http://link.springer.com/article/10.1007\%2Fs00181-013-0738-x (accessed on 16 May 2020). [CrossRef] 
9. Butu, A.; Vasiliu, C.D.; Rodino, S.; Brumă, I.S.; Tanasă, L.; Butu, M. The process of ethnocentralizing the concept of ecological agroalimentary products for the Romanian urban consumer. Sustainability 2019, 11, 6226. [CrossRef]

10. Kaminski, R.; Marcysiak, T.; Prus, P. The development of green care in Poland. In Proceedings of the 2018 International Conference “Economic Science for Rural Development”, Jelgava, Latvia, 9-11 May 2018; pp. 307-315.

11. Prus, P. The role of higher education in promoting sustainable agriculture. In Corporate Social Responsibility and Business Ethics in the Central and Eastern Europe; Nomos Verlagsgesellschaft Mbh \& Co.: Baden-Baden, Germany, 2019; pp. 99-119.

12. Małysa-Kaleta, A. Kierunki oraz determinanty zmian struktury konsumpcji w krajach Unii Europejskiej. Studia Ekon. 2015, 231, 56-79.

13. Neale, A. Zrównoważona konsumpcja. Źródła koncepcji i jej zastosowanie. Pr. Geogr. 2015, 141, 141-158.

14. The Competitive Position of the European Food and Drink Industry. Available online: https://ec. europa.eu/growth/content/study-competitive-position-european-food-and-drink-industry-0_pl (accessed on 3 May 2020).

15. Brown, C. Consumers' preferences for locally produced food: A study in southeast Missouri. Am. J. Altern. Agric. 2003, 18, 213-224. [CrossRef]

16. Kryk, B. Konsumpcja zrównoważona a proekologiczne style życia. Stud. Proc. Pol. Assoc. Knowl. Manag. 2011, 51, 206-218.

17. Petrini, C. Slow Food: The Case for Taste; Columbia University Press: New York, NY, USA, 2001.

18. Kozłowski, W.; Rutkowska, A. Megatrendy w konsumpcji żywności a marketing społecznie zaangażowany. Handel Wewnętrzny 2018, 2, 261-269.

19. Gębski, J.; Kosicka-Gębska, M.; Kwiecińska, K.; Jeznach, M. Bariery i szanse związane z zakupami żywności przez mieszkańców Warszawy w Internecie. Handel Wewnętrzny 2018, 1, 17-25.

20. Cvijanović, D.; Ignjatijević, S.; Vapa Tankosić, J.; Cvijanović, V. Do local food products contribute to sustainable economic development? Sustainability 2020, 12, 2847. [CrossRef]

21. Soroka, A.; Wojciechowska-Solis, J. Consumer awareness of the regional food market: The case of Eastern European border regions. Foods 2019, 8, 467. [CrossRef]

22. Jęczmyk, A. Tradycyjne i Regionalne Produkty Żywnościowe Jako Element Rozwoju Gospodarstw Agroturystycznych; Wydawnictwo Studia KPZK: Warszawa, Poland, 2015.

23. Khan, F.; Prior, C. Evaluating the urban consumer with regard to sourcing local food: A heart of England study. Int. J. Consum. Stud. 2010, 34, 161-168. [CrossRef]

24. Zepeda, L.; Leviten-Reid, C. Consumers' views on local food. J. Food Distrib. Res. 2004, 35, 1-6.

25. Selfa, T.; Qazi, J. Place, taste, or face-to-face? Understanding producer-consumer networks in "Local" food systems in Washington State. Agric. Hum. Values 2005, 22, 451-464. [CrossRef]

26. Wojciechowska-Solis, J. Promotion of local products in regional development, agrarian perspectives XXVII.food safety-food security. In Proceedings of the 27th International Scientific Conference, Prague, Czech Republic, 19-20 September 2018; pp. 436-442.

27. Żakowska-Biemans, S.; Kuc, K. Żywność tradycyjna i regionalna w opinii i zachowaniach polskich konsumentów. Żywność Nauka Technol. Jakość 2009, 16, 105-114.

28. Siegrist, M. Factors influencing public acceptance of innovative food technologies and products. Trends Food Sci. Technol. 2008, 19, 603-608. [CrossRef]

29. Jeżewska-Zychowicz, M.; Jeznach, M.; Kosicka-Gębska, M. Akceptacja Nowych Produktów Żywnościowych i jej Uwarunkowania; Wydawnictwo SGGW: Warszawa, Poland, 2012.

30. Tenbült, P.; de Vries, N.K.; Dreezens, E.; Martijn, C. Perceived naturalness and acceptance of genetically modified food. Appetite 2005, 45, 47-50. [CrossRef] [PubMed]

31. Jeżewska-Zychowicz, M. Impact of beliefs and atitudes on young consumers' wilingness to use functional food. Pol. J. Food Nutr. Sci. 2009, 59, 183-187.

32. Polish Ministry of Agriculture and Rural Development. Available online: minrol.gov.pl (accessed on 23 June 2019).

33. Naspeti, S.; Bodini, A. Consumer perception of local and organic products: Substitution or complementary goods? Int. J. Interdiscip. Soc. Sci. Annu. Rev. 2008, 3, 111-122. [CrossRef] 
34. Żakowska-Biemans, S.; Ozimek, I.; Szlachciuk, J.; Matusiak, K. Czynniki wpływające na rozwój lokalnej produkcji i dystrybucji żywności w opinii konsumentów. Handel Wewnętrzny 2017, 4, 357-369.

35. Prus, P. Farmers' opinions about the prospects of family farming development in Poland. In Proceedings of the 2018 International Conference "Economic Science for Rural Development", Jelgava, Latvia, 9-11 May 2018; pp. 267-274.

36. Gulbicka, B.; Kwasek, M. Wpływ Globalizacji na Wyżywienie Ludności w Polsce; Wyd. Instytut Ekonomiki Rolnictwa i Gospodarki Żywnościowej; Państwowy Instytut Badawczy: Warszawa, Poland, 2007.

37. Jarossová, M.; Pazúriková, V. Traditional and regional foods from the Slovak consumer's view. In Proceedings of the 5th International Scientific Conference on Trade, International Business and Tourism: Application of Knowledge in Process of Business Dynamization in Central Europe, Bratislava, Slovakia, 16-17 October 2014; pp. 197-206.

38. Jensen, J.D.; Christensen, T.; Denver, S.; Ditlevsen, K.; Lassen, J.; Teuber, R. Heterogeneity in consumers' perceptions and demand for local (organic) food products. Food Qual. Prefer. 2019, 73, 255-265. [CrossRef]

39. Bryła, P. Regional ethnocentrism on the food market as a pattern of sustainable consumption. Sustainability 2019, 11, 6408. [CrossRef]

40. Kalabova, J.; Turcinkova, J. Preferences of Consumers When Shopping for Regional Products. Economic Science for Rural Development. 2011, 28, 56-60.

41. Eurostat. 2019. Available online: http://appsso.eurostat.ec.europa.eu/nui/show.do?dataset=isoc_ec_ibuy\& lang=en (accessed on 21 June 2019).

42. Szajt, M.; Rafałko, S. Nowe trendy zakupów on-line w Polsce na tle innych państw europejskich. Res. Rev. Czest. Univ. Technol. 2017, 28, 50-58. [CrossRef]

43. Bryła, P. Organic food online shopping in Poland. Br. Food J. 2018, 120, 1015-1027. [CrossRef]

44. Bryła, P. The role of appeals to tradition in origin food marketing: A survey among Polish consumers. Appetite 2015, 91, 302-310. [CrossRef]

45. Grzywińska-Rapca, M.; Grzybowska-Brzezińska, M. Rola Internetu w realizacji działań marketingowych firmy i zdobywaniu nowych segmentów klientów. Rocz. Kol. Anal. Ekon. 2016, 40, 333-341.

46. Gemius Polska. E-commerce w Polsce 2017. Gemius dla e-Commerce Polska 2018. Warszawa. Available online: https://branden.biz/wp-content/uploads/2018/07/E-commerce_w_Polsce_2017.pdf (accessed on 30 March 2020).

47. Urząd Statystyczny w Szczecinie, Społeczeństwo informacyjne w 2018, Wydawnictwo: Ośrodek Statystyki Nauki, Techniki, Innowacji i Społeczeństwa Informacyjnego. 2018. Available online: https://szczecin.stat.gov.pl/osrodki/osrodek-statystyki-nauki-techniki-innowacji-i-spoleczenstwainformacyjnego/dane-1300/ (accessed on 30 March 2020).

48. Hanus, G. Consumer behaviour during online grocery shopping. In Proceedings of the CBU International Conference on Innovations in Science and Education, Prague, Czech Republic, 23-25 March 2016; pp. 10-13.

49. Barska, A. Zaufanie konsumentów generacji Y wobec handlu elektronicznego. In Handel Wewnętrzny w Polsce 2009-2014; Wydawnictwo IBRIK: Warszawa, Poland, 2014; pp. 368-385.

50. PizzaPortal. Klikasz i jesz. Raport o rynku dostaw jedzenia w Polsce w 2018 roku, Warszawa. Available online: https://pizzaportal.pl/i/klikasz-i-jesz-raport-o-rynku-dostaw-jedzenia-w-polsce-2018-r/ (accessed on 3 May 2020).

51. Wang, O.; Somogyi, S. Consumer adoption of online food shopping in China. Br. Food J. 2018, 120, $2868-2884$. [CrossRef]

52. Kaur, H.; Shukla, R.K. Consumer's attitude for acceptance of online grocery shopping in India. Int. J. Curr. Res. 2017, 9, 50776-50784.

53. Kooti, F.; Lerman, K.; Aiello, L.M.; Grbovic, M.; Djuric, N.; Radosavljevic, V. Portrait of an online shopper: Understanding and predicting consumer behavior. In Proceedings of the Ninth ACM International Conference on Web Search and Data Mining, San Francisco, CA, USA, 22-25 February 2016; pp. 205-214.

54. Finotto, V.; Mauracher, C.; Procidano, I. Socio-demographic factors and online shopping for food and beverage: An analysis of Italian consumers. In Proceedings of the 12th Annual Conference of the EuroMed Academy of Business, Thessaloniki, Greece, 18-20 September 2019; pp. 225-239.

55. Handel 2019. Available online: https://www.portalspozywczy.pl/handel/wiadomosci/w-ciagu-pieciu-latsprzedaz-zywnosci-przez-internet-wzrosnie-o-polowe,167904.html (accessed on 3 May 2020). 
56. Tundys, B. Krótki łańcuch dostaw produktów spożywczych (SFSC)-ujęcie teoretyczne i praktyczne. Studia Ekon. 2015, 249, 94-110.

57. Mirosa, M.; Lawson, R. Revealing the lifestyles of local food consumers. Br. Food J. 2012, 114, 816-825. [CrossRef]

58. Markuszewska, A.; Prior, A.; Strano, A.; Bálint, B.; Midoux, B.; Bros, C.; Koutsaftaki, C.; Jochum, C.; Buffet, C.; McGlynn, D.; et al. Local Food and Short Supply Chains, EU Rural Review; European Network for Rural Development: Brussels, Belgium, 2012; Available online: https://enrd.ec.europa.eu/sites/enrd/files/fms/pdf/ E8F24E08-0A45-F272-33FBA6309E3AD601.pdf (accessed on 21 July 2019).

59. Arsil, P.; Li, E.; Bruwer, J.; Lyons, G. Exploring consumer motivations towards buying local fresh food products. Br. Food J. 2014, 116, 1533-1549. [CrossRef]

60. Bezpieczeństwo i Higiena Żywności. Available online: Zywnosc.com (accessed on 28 August 2019).

61. Hinton, P.R.; McMurray, I.; Brownlow, C. SPSS Explained; Routledge: Abingdon, UK, 2014.

62. Stanisz, A. Przystępny kurs Statystyki z Zastosowaniem STATISTICA.PL; StatSoft Polska: Kraków, Poland, 2007.

63. Główny Urząd Statystyczny. Population, Size and Structure by Territorial Division. Available online: www.demografia.stat.gov.pl (accessed on 15 January 2020).

64. Grzybowska-Brzezińska, M.; Rudzewicz, A. Handel elektroniczny artykułami żywnościowymi z perspektywy klienta. Probl. Zarzadzania 2016, 14, 166-175. [CrossRef]

65. Hidalgo-Milpa, M.; Arriaga-Jordán, C.M.; Cesín-Vargas, A.; Espinoza-Ortega, A. Characterisation of consumers of traditional foods: The case of Mexican fresh cheeses. Br. Food J. 2016, 118, 915-930. [CrossRef]

66. Espejel-Blanco, J.E.; Camarena-Gómez, D.M.J.; Sandoval-Godoy, S.A. Alimentos tradicionales en Sonora, México: Factores que influyen en su consume. Rev. de Cienc. Adm. y Soc. 2014, 24, 127-139. [CrossRef]

67. Götze, F.; Mann, S.; Ferjani, A.; Kohler, A.; Heckelei, T. Explaining market shares of organic food: Evidence from Swiss household data. Br. Food J. 2016, 118, 931-945. [CrossRef]

68. Bodini, A.; Zanoli, R. Competitive factors of the agro-food e-commerce. J. Food Prod. Mark. 2011, 17, $241-260$. [CrossRef]

69. Fernández-Ferrína, P.; Calvo-Turrientes, A.; Bandec, B.; Artaraz-Miñóna, M.; Galán-Ladero, M.M. The valuation and purchase of food products that combine local, regional and traditional features: The influence of consumer ethnocentrism. Food Qual. Prefer. 2018, 64, 138-147. [CrossRef]

70. Galli, F.; Brunori, G. Short Food Supply Chains as Drivers of Sustainable Development. 2013. Available online: http://www.foodlinkscommunity.net/fileadmin/documents_organicresearch/foodlinks/ CoPs/evidence-document-sfsc-cop.pdf (accessed on 23 June 2019).

71. Ramus, K.; Nielsen, N. Online grocery retailing: What do consumers think? Internet Res. 2005, 15, 335-352. [CrossRef]

72. Sajdakowska, M.; Jankowski, P.; Gutkowska, K.; Guzek, D.; Żakowska-Biemans, S.; Ozimek, I. Consumer acceptance of innovations in food: A survey among Polish consumers. J. Consum. Behav. 2018, 17, 1-15. [CrossRef]

73. Wyrwa, J.; Barska, A. Innovations in the food packaging market: Active packaging. Eur. Food Res. Technol. 2017, 243, 1681-1692. [CrossRef]

74. Nganje, W.E.; Hughner, R.S.; Lee, N.E. State-branded programs and consumer preference for locally grown produce. Agric. Resour. Econ. Rev. 2011, 40, 20-31. [CrossRef]

75. Commission Staff Working Document 2013 on Various Aspects of Short Food Supply chains Accompanying the Document Report from the Commission to the European Parliament and the Council on the Case for a Local Farming and Direct Sales Labelling Scheme. 2013. Brussels. Available online: https://ec.europa.eu/ economy_finance/publications/pages/publication16065_en.pdf (accessed on 3 January 2020).

76. Opinion of the Committee of the Regions on "Local food systems" (outlook opinion). Off. J. Eur. Union 2011. C 104/1. Available online: https://eur-lex.europa.eu/legal-content/EN/TXT/HTML/?uri=OJ:C:2017:075: FULL\&from=SK (accessed on 3 January 2020).

(C) 2020 by the authors. Licensee MDPI, Basel, Switzerland. This article is an open access article distributed under the terms and conditions of the Creative Commons Attribution (CC BY) license (http://creativecommons.org/licenses/by/4.0/). 